\title{
Corrigendum
}

\section{A case of mistaken identity? - CORRIGENDUM}

Robert H. Anderson, Simon D. Bamforth, Saurabh K. Gupta

doi:10.1017/S1047951117002049, Published online: 30 October 2017

First published online: 28 November 2017

The authors apologise for an error in the title. It should be as follows:

Fifth arch artery - a case of mistaken identity?

\section{Reference}

Robert H. Anderson, Simon D. Bamforth, Saurabh K. Gupta. A case of mistaken identity? Cardiol Young. Published by Cambridge University Press, 30 October 2017. doi: 10.1017/S1047951117002049. 